\title{
Economic Recession \& its Effect on Consumer Buying Behaviour towards Imported Foods in South-East Region of Nigeria
}

\author{
1.Okoro, Oliver Chibuzor \\ 2.Asiagwu, Ekene Catherine PhD \\ ${ }^{3}$ Okoh-Inya Agha, Maria Eleje \\ 1.Department of Marketing, Akanu Ibiam Federal Polytechnic, Unwana, \\ P.M.B. 1007, Afikpo, Ebonyi state, Nigeria. \\ GSM NO: +234 8038410655 \\ Corresponding Author: olivechikoro@yahoo.com \\ ${ }^{2}$.Delta State School of Marine Technology, Burutu, P.M.B.1060,Warri, Delta State. Nigeria \\ GSM NO: +234 7061675648 \\ ekenenwaokolie@gmail.com \\ ${ }^{3}$ Department of Marketing, Akanu Ibiam Federal Polytechnic, Unwana, \\ P.M.B. 1007,Afikpo, Ebonyi state, Nigeria \\ GSM No: +234 8032249804 \\ Email: mariagoldokoh@yahoo.com \\ DOI: 10.29322/IJSRP.11.08.2021.p11638 \\ http://dx.doi.org/10.29322/IJSRP.11.08.2021.p11638
}

\begin{abstract}
This study investigated the economic recession effect on consumer buying behaviour towards imported foods in South-East Region of Nigeria. This became necessary following the devastating effect of recent economic recession on Nigerian economy due to the global Covid-19 Pandemic. Relevant conceptual, theoretical and empirical literatures were reviewed. The enquiry drives its theoretical foundation from the theory of planned behaviour. Descriptive Survey research method was used to investigate the issue of concern. Sample size of 384 was selected from the consumers of imported foods in South-East Region of Nigeria, using Cochran formula. Structured questionnaire was employed as the instrument of data collection. The data generated were analyzed using descriptive statistics, correlation analysis and ordinary least square regression technique. The result indicates that economic recession has a significant effect on brand switching behavior. The finding further indicates that economic recession has a significant effect on price conscious behavior. Similarly, economic recession was found to have significant effect on impulse buying behavior for imported foods. The result further showed that economic recession has a significant effect on consumers' shopping habits. Based on the findings, the study concludes that economic recession has significant effect on consumer buying behaviour for selected imported foods in South-East Region of Nigeria. The study recommends that companies and/or dealers should monitor the behaviour of their consumers in order to reduce the effect of brand switching behaviour during recession on their products.
\end{abstract}

Key Words: Economic Recession, Consumer buying behavior, Consumer goods, brad switching, Price conscious, Impulse buying.

\section{INTRODUCTION}

Consumer behaviour is an important and constant decision-making process of searching, purchasing, using, evaluating and disposing of products and services. People usually purchase those products and services which are of maximal utility. Samuleson and Nordhaus (2000) claim consumers try to maximize their utility, satisfaction or joy by purchasing consumer goods. Taking the lifestyle and its factors into consideration, consumers are able to create some opinion and attitudes to particular products. The combination of one' s lifestyle, different factors and attitudes affect the consumer decision- making process as well as the consumer behavior (Valaskova \& Klieštik, 2015). Understanding consumers' buying pattern is one of the most important factors in the success of any organization (Sharma \& Sonwalkar, 2013). The consumer is the most elemental basis for business organization and therefore their behavior is of great importance for successful marketing and financial affluence (Mansoor \& Jalal, 2011). Consumer behavior can vary vastly between products, individuals, culture and economic situations and has changed substantially over time (Kar, 2010). When 
consumers' buying behavior changes, many entities will have to make changes to their usual activities. By studying and predicting consumer behavior, a business can understand their costumers' needs and work on fulfilling them as well as meeting their expectations. Therefore, understanding how consumers behave helps companies maintain prosperity and contribute to their long term objectives (Nistorescu \& Puiu 2009).

Researches on buying behavior during downturns in the economy suggest that consumers adapt their behavior to new and changed situations (Ang, Leong \& Kotler, 2000; Curtin 2003). When consumers adopt new strategies and tactics as a reaction to changing economic circumstances, companies and/or dealers need to understand how their customers reacts and how their behavior changes to develop strategies to meet and capitalize on different needs, values and consumption patterns (Amalia \& Ionut, 2009). It is vital that companies and/or dealers understand the nature and the scale of the change in consumer behaviours and attitudes to formulate marketing strategy that allows them to achieve objectives concerning sales, market share and profits (Shipchandler, 1982). From psychological as well as a financial point of view, consumers experiencing crisis behave differently from those enjoying a blossoming economy (Ang, Leong \& Kotler, 2000). This can be, at the same time, an opportunity and a threat for companies, which makes it even more important than before to monitor and listen to consumers. Business strategies that were appropriate during a blossoming economy may become ineffective in a recession. Businesses may need to change their target market and adjust their marketing mix to reflect values sought by consumers experiencing economic crisis. For companies and/or dealers to succeed in this, it is vital for them to understand how an economic crisis affects consumers (Ang et al, 2000).

Historically, the economy goes through business cycle with its upswings and downturns and both individuals and businesses are affected along the way. The aftermath of the majority of severe economic crises that have occurred shared three characteristics (Reinhart \& Rogoff, 2009). The first characteristic is deep and prolonged asset market collapse. The second characteristic is associated with profound decline in output as well as employment and the third characteristic is that the real value of government debt tends to explode mainly because of collapse in tax revenues due to output contractions (Reinhart \& Rogoff, 2009). The economic cycle can have an important impact on consumption patterns, with expenditure usually rising during the periods of economic upturn. When an economy is booming, there is often an upturn in the consumption of luxury goods and consumer durables. And vice versa, during the periods of recession, disposable income is reduced and consumer confidence usually falls. A slowdown or contraction in economic activity often results in fewer luxury purchases being made (Eurostat European Commission 2009).

Flatters and Willmott (2009) categorize recession into two broad categories: brief and shallow or catastrophically deep and enduring. Most downturns fall into the previous category, provoking short-term change in consumer behavior that depend on the causes of the crisis and who are most affected by it. Consumption trends resulting from this group of recessions usually rebound rather quickly when the recession ends, however, at different rates depending on sector. The recessions in the latter category reshape consumers' minds and have long-term impacts on buying behavior (Flatters \& Willmott, 2009). During the recession, but mostly after, the purchasing behaviour of all types of consumers suffers some dramatic changes (from the companies' and/or dealers' viewpoint) and these changes are determined by a series of important factors. Perriman, Ramsaran-Fowdar \& Baguant (2010) think that the most obvious factor is represented by the uncertainty of the future. During the period of recession, many unexpected changes bring to the consumers a feeling of insecurity, they doubt about the nature of the upcoming events and, so, they become much more careful when dealing with certain expenses (Pop \& Rosca, 2009). During the recession people tend to use less money on goods that are not considered as necessities to buy because the consumers prefer to save money in the fear of losing it. This has a negative effect on the economy; both consumers and businesses suffer from this chain reaction. During economic downturns the cost of living rises. When people are losing their job places during recession, the consumers are not buying goods and companies and/or dealers are not making money (Valaskova \& Kliestik, 2015).

The current recession in Nigeria has serious consequences for companies and/or dealers and individuals as mentioned before, consumer behavior are subject to change, which can result in different consumption trends. The study of consumption trends and patterns among consumers is important for several reasons. The current recession has profound impact on consumers' consumption trends by propelling some consumer trends forward and slowing, ending or reversing other trend. Based on the foregoing, this study examined the effect of economic recession and its effecton consumer buying behavior for imported foods in South-East Region of Nigeria. Specifically, the study examined the economic recession effect on brand switching behavior, price conscious behavior, impulse buying behavior and consumers' shopping habits in South-East Region of Nigeria.

\section{L ITERATURE REVIEW}

\subsection{Economic Recession}

Recession is a period of general economic decline; defined as a decline in GDP for the period of two or more quarters, it is an international or national event. The roots of a recession and its opening point actually rest in the quite a few quarters of positive but slowing growth before the recession really begins. Sometimes in a mild recession the initial quarter of negative growth is followed by the minor positive growth, then negative growth is back and the recession trend continues. It comes with a drop in the stock market, a rise in unemployment, and a turn down in house market (Armalia \& I). Recession refers to the situation in which the economy of a country suffers a fall caused by several financial factors: a decrease in the GDP, increased inflation etc. The economic literature also reminds about the term "financial crisis" which describes "the situation in which the supply of money is outpaced by the demand for money (Ghe, 2009). If a country's economy is in recession it means that the GDP (Gross Domestic Product) of an economy depreciates continously for six months. If the GDP decreases more than ten percent and lasts over three years it is called depression (Abishek, 2009).

This publication is licensed under Creative Commons Attribution CC BY.

http://dx.doi.org/10.29322/IJSRP.11.08.2021.p11638

WwW.ijsrp.org 
Sultan (2016) sees a recession as a general downturn in any economy. He noted that a recession is associated with high unemployment, slowing gross domestic product, and high inflation. It is visible in industrial production, employment, real income and wholesale-retail trade. The technical indicator of a recession is two consecutive quarters of negative economic growth as measured by a country's gross domestic product (GDP). Noko (2016) defined recession as a significant decline in economic activity spread across the economy, lasting more than a few months, normally visible in gross domestic product, real income, employment, industrial production and wholesales/retail sales.

Amadeo (2017) noted that a recession is when the economy declines significantly for at least six months. That means there's a drop in the following five economic indicators: real GDP, income, employment, manufacturing, and retail sales. A recession is usually underway when there are several quarters of slowing but still positive growth. Often a quarter of negative growth will occur, followed by positive growth for several quarters, and then another quarter of negative growth. Recessions generally occur when there is a widespread drop in spending (an adverse demand shock). This may be triggered by various events, such as a financial crisis, an external trade shock, an adverse supply shock or the bursting of an economic bubble.

Understanding the sources of recessions has been one of the enduring areas of research in economics. There are a variety of reasons recessions take place. Some are associated with sharp changes in the prices of the inputs used in producing goods and services. For example, a sharp increase in oil prices can be a harbinger of a coming recession. As energy becomes expensive, it pushes up the overall price level, leading to a decline in aggregate demand. A recession can also be triggered by a country's decision to reduce inflation by employing contractionary monetary or fiscal policies. When used excessively, such policies can lead to a decline in demand for goods and services, eventually resulting in a recession (Stijn \& Kose, 2009). Some recessions, including the current one, are rooted in financial market problems. Sharp increases in asset prices and a speedy expansion of credit often coincide with rapid accumulation of debt. As corporations and households get overextended and face difficulties in meeting their debt obligations, they reduce investment and consumption, which in turn leads to a decrease in economic activity. Not all such credit booms end up in recessions, but when they do, these recessions are often more costly than others. Recessions can be the result of a decline in external demand, especially in countries with strong export sectors (Stijn, Kose \& Terrones, 2008).

\section{Consumer Buying Behaviour}

For an enduring period of time, one of the major fields of academic research has been consumer behaviour, which has resulted in several descriptions being brought forward by scholars (Sinem, 2014). Consumer buying behavior can also be defined as a psychological process that consumers undergo when they understand what their needs are and the way they are going to resolve them. Consumer buying behaviour studies how buyers behave or react when they are purchasing a product. It is a process where the buyer identifies and studies the features and the pros and the cons of the product before buying it (Kumra, 2007)

Solomon (2009) defines consumer behaviour as not only determined by how consumers

purchase but also how having or, not having certain things affect a consumers' behaviour in life

their perception of themselves in society. One's possessions affect the image of self as a consumer but also the perception he or she has of others. Solomon continues to define consumer behaviour as "the study of processes involved when individuals or groups purchase, use or dispose of products, services, ideas or experiences to satisfy needs and desires" (Solomon, 2009). Consumer behaviour is the sum of people's behaviour that consumer based on income and access to goods and conduct operations in order to meet their own material and cultural needs during everyday life. It includes consumer behaviour methods, processes and changes, etc. The demand of consumer has strong autonomy. Its changes depend on consumer behaviour (Kotler \& Armstrong, 2007).

Consumer behavior can be defined as the study of the processes that individuals or groups go through in making their purchasing choices in order to satisfy their needs (Sharma \& Sonwalker, 2013). In broad context, consumer buying behavior can be seen as a subset of human behavior and the several factors affecting individuals in their daily lives also influence their purchasing activities and decisions. Consumer buying behavior is both a psychological and a social process, including both mental and physical activities, and a combination of internal and external factors influence and determine the buying behavior of consumers (Modi \& Jhulka, 2012). Perner (2008) stated that consumer behavior involves the study of the processes which individuals, groups, or organizations perform to acquire products, services, experiences, or ideas to satisfy their needs and how these processes have impacted the consumer and society. The role that consumers play in these days is very crucial to businesses' survival. It is the driving force behind the success of many businesses, because most of the contemporary consumers spend major time on buying decisions. Kotler and Armstrong (2012) have identified four characteristics that strongly influence consumer buying behavior. Those are cultural, social, personal and psychological characteristics. Consumer buying behavior is a complex and dynamic concept in nature and because of the various factors influencing consumers; their behavior varies both between individuals as well as the situations the individual is in (Modi \& Jhulka, 2012).

There are four distinctive classes of consumer buying behaviour identified by the literature. What differentiate these classes can be observed thorough the frequency of occurrence, emotional involvement, decision making complexity and risk. These types are known to be: programmed behaviour; limited decision making buying behaviour; extensive decision-making buying behaviour and impulsive buying (Arnould, Price \& Zinkhan, 2002). Programmed behaviour (also called habitual behaviour) is distinguished by low complexity and little information search, this process is usually known as routine purchase of low cost items that consumer is used to buy out of habit: such as coffee, newspapers, bus tickets, etc (Noko, 2016). Limited decision-making buying behaviour involves reasonable level of decision making and relatively low amount of information search in order to generate a purchase. An example of This publication is licensed under Creative Commons Attribution CC BY. 
this type can be the purchase of clothes when someone can easily get information on the product and its quality and spend short time selecting the desired outfit (East, 1997). The extensive decision-making buying behaviour is identified as being the opposing type to the limit decision-making buying behavior (Foxall \& Goldsmith, 1994). In this process the consumer would spend a relatively longer share of time in information search and would take longer period to make a decision regarding this purchase because this process is usually adopted when purchasing infrequent expensive product that takes a large share of the consumer's income and involves higher psychological risk (Peter \& Olson, 2007). The last type of buying behaviour identified by the literature is the impulsive buying. It is a decision made unconsciously and induced by an

external stimulus that would make a specific product to appear attractive and irresistible to the consumer (Wells \& Prensky, 1997).

It can be seen in the four listed behaviours above, that the fundamental driving force behind these behaviour is the consumer's emotion. It is the primary determinant of buying behaviour that is highly influenced by some external and internal factors (Chaudhuri, 2006). Although emotion is a subjective issue that differs according to individual attributes and situational contexts, it is still regarded as the most elemental determinant of planned and unplanned buying behavior (Havlena \& Holbrook, 1986). The unplanned behaviour matches greatly the impulsive buying which is driven mostly by emotional forces (Laros \& Steenkamp, 2005). On the other hand, the planned behaviour is a result of rationality rather than emotionality because planned behaviour is a complex process for the great deal of information needed and the long time spent on selection. Although the planned behaviour is primarily induced by emotions, it is still considered to be less emotional than unplanned.

\section{Theoretical Framework}

This study is anchored on the theory of planned behavior. In 1988, The Theory of Planned Behavior was added to the existing model of the Theory of Reasoned Action as an extension of this model, and aims to further explain the link between attitudes and behavior. The major difference between these models is the addition of a third determinant of behavioral intention, known as perceived behavioral control, which is determined by two factors: control beliefs and perceived power (Amadeo, 2017). The theory of planned consumer behaviour deals with the consumer's perception of complexity. Simply stated, the planned consumer buying behaviour is explained as how difficult the consumer selects and secures a product. The level of complexity is driven by the opportunity cost of the alternatives as well as the transaction costs like time, money and effort (Chaudhari, 2006). This theory also presents the concept of 'perceived behaviour al control' as a vital component of the planned behaviour al intention. The theory explains the important role of consumer's perception of complexity as well as the essential function of risk associated with every purchase action (Posthuma \& Dworkin, 2000). It is observed that as the consumer's expectation of a negative outcome increases this increases the level of perceived risk (Hansen et al, 2004).

According to the TPB, people's actions reflect their intentions and perceptions of control over the behavior, and intentions are a result of attitudes, subjective norms, and perceived behavioral control (East, 1997). Perceived behavioral control indicates that an individual's motivation is influenced by how difficult the behaviors are perceived to be, as well as how successfully the individual can or cannot perform the activity (Kumra, 2007). In addition, if a person holds strong control beliefs about the existence of factors that will facilitate a behavior, then the individual will have high perceived control over a behavior. Conversely, the person will have a low perception of control if she holds strong control beliefs that impede the behavior. This perception can reflect past experiences, anticipation of upcoming circumstances, and the attitudes of the influential norms that surround the individual.

Furthermore, attitudes are positive or negative feelings about the behavior, and social norms reflect a persons feeling about social acceptance in regards to performing the specific behavior, as stated in the Theory of Reasoned Action (Abishek, 2009). This information shows that an individual's behavior is influenced most by existing beliefs, ideas of control, and ways of life. It also shows that behavior is largely influenced by how that decision will affect the way they are perceived by their social circle. Consumer behavior is not only influenced by ones own beliefs and attitudes, it is influenced by others attitudes as well. In terms of consumer decision-making, models have been proposed to help categorize the steps consumers take when evaluating purchase decisions.

Furthermore, the theory of planned behaviour specifically introduces the concept of 'perceived behavioural control' as an essential determinant of the process of planned behavioural intention (Posthuma \& Dworkin, 2000). In this respect, the TBA not only does explain the importance of the consumer's perception of the levels of complexity with which a particular purchase can be associated, but also outlines the essential role of the buying risk which consumers are likely to bear during purchases.

The perceived risk perspective can be recognised as a multidimensional construct. High perceived risk can result from the consumer's expectation of experiencing a negative outcome from a buying interaction (Lim, 2003). In this respect if any situational determinants of the process of purchasing reveal a possibility of negative outcome, it can be suggested that this is likely to increase the levels of consumers' perceived risk. In this context, situational determinants of these types can be recognised to be the transactional costs, which are associated with every purchase consumers make. In other words, the higher the transactional costs (i.e. money, time, effort, etc.) the greater the likelihood of higher levels of perceived risk (Hansen, 2006).

On the other hand, perceived risk is not only determined by the transactional costs, which consumers identify. Contrary, perceived risk is often influenced by situational variables and outcomes, which the consumer fails to recognise. In other words, if a consumer is unable to clearly identify the possible outcome of a particular buying transaction, the consumer would be less inclined to purchase. In this respect, it can be concluded that another significant determinant of buying risk is uncertainty (Shim et al., 2001). This is why planned behaviour is associated with complex decision-making processes, which is characterised by extensive information gathering (Peter \& Olson, 2007). 


\section{Empirical Review}

Kiran (2011) investigated the impact of recession on buying behavior of Indian consumers. The study was conducted on a sample of 50 retailers in Navi Mumbai. The data generated were analyzed using charts and correlation analysis. The results indicated that Hypermarkets, supermarkets witness a greater change in shopping behavior than the kirana stores. They were also suggestive of the fact that the type of retail format would adversely affect the footfall of consumers for luxury items. The study also ascertained that the customers who shop frequently are more likely to respond to discounts vis-à-vis others. The findings recorded showed that the customers who shop frequently are more likely to spend a higher amount for shopping. It was also revealed that customers who shop more frequently are likely to witness higher fluctuations for luxury items than for regular items. It indicates, therefore that shopping for luxury items faces more fluctuations than regular shopping items, which indicates that customers shopping for luxury items may be postponed in times of recession but they continue to shop for regular items.

Hrund (2016) examined the impact of economic crisis on buying behavior and consumer attitude. Consumer attitudes towards shopping and brand switching were compared from four points of reference where changes occurred in the economic environment. The sample of the

research consisted of Icelandic individuals, 18 years old and older. Consumers' self-reported attitudes towards statements related to attitude towards shopping and brand switching were extracted from the Target Group Index and compared using one-way between groups analysis of variance to reveal if there was a statistically significant difference in consumers' attitudes between the four years analyzed. The study shows that consumer attitudes toward shopping and brand switching are somewhat influenced by the economic environment. The results also show that when the economy recovers, consumers stick to some of the changes they made during the recession while they return to other pre-recession attitudes and behavior. Consumers were also found to make new changes to their behavior and attitude in the economic recovery.

Masarrat and Jha (2014) assessed the impact of recession on consumer's behaviour in Dubai. The purpose of the study is to understand the impact of global recession on consumer shopping behaviour moreover how consumer consumption and saving pattern changed across different product categories during and after recession. A total of 235 consumers across shopping malls, beaches, parks in Dubai were personally surveyed with a structured questionnaire. Paired sample t-test \& ANOVA was used to test the effect of recession on consumption pattern of different good and leisure related activities. The study provides empirical evidence that the priorities of the consumer have significantly changed after recession. The study concludes that recession has impact on the shopping behaviour of the customers especially in Islamic Country-Dubai.

Saurabh and Devik (2014) examined the effect of recession on the buying behavior of consumers in New Delhi during the economic slowdown of 2013. The study was conducted in the West Delhi region. The purpose of this study was to examine the effect of recession on buying attitude of consumers, taking into consideration differences in spending in their goods consumption on different food, convenience and luxury items. With further expounding into the enquiry of change in shopping patterns of customers due to increase in prices or decrease in income and to analyze whether decrease in purchasing capacity of the customers have adulterated their preference for branded products. The results were checked in accordance with

whether recession affects the buying behavior or not. A survey was conducted in a region of west Delhi, with the total number of respondents being 100. The sample space is divided on the basis

of age and family income. Percentages were used to analyze the data. The study found that consumer preference towards necessities increased whereas purchase of luxury items decreased, gold being an exception. In times of hardships, the branded products lost their cause to prices with people turning towards inferior quality products.

Valaskova and Klieštik (2015) examined the behavioural reactions of consumers to economic recession in Slovak consumer market. The study aimed to examine the relationship between changes in consumer behaviour and the age structure of consumers, the length of crisis and disposable income. Survey research design was adopted with the aim of describing the key changes in behavior. The study used Kendall correlation coefficient which is designed to measure the dependence between two ordinal variables. The study found that changes in consumer buying behavior and the age structure of the population have no statistically significant dependence. It means that changes in consumer behaviour are not dependent on the age of the population and the economic recession has affected the consumers of all age categories. The study also found that changes in consumer behaviour are dependent on the income of consumers. Finally, the study revealed that changes in consumer behaviour are dependent on the length of the economic recession.

Mansoor and Jalal (2011) examined the global business crisis and consumer behavior in Kingdom of Bahrain. This research aims to study the impact of the Global Business Crisis on Bahraini consumers, investigate their perception of this problem and whether their consumption behaviour has changed as a result. One sample T-test was used to test the hypotheses formulated. The study found that Bahraini consumer is aware of the Global Financial Crisis and its effects on consumption, inflation and on the country's economy. The study also found that the behaviour of Bahraini consumers did change in effect of the global financial crisis, these is a shift from expensive to inexpensive substitute, a shift from luxury to essential, a shift from huge quantities to small quantities and a shift from consumption to saving.

Obai (2015) examined the effects of Canadian recession on university students' buying behavior. This paper is an effort to understand the theoretical framework of the financial crisis, its causes, consequences, and impact on the behavior of Canadian students' purchasing patterns. To address the research questions and test the hypothesis of whether Canadian students at the university level were aware of the extent and consequences of the financial crisis, and to understand the impact on Canadian students' This publication is licensed under Creative Commons Attribution CC BY. 
purchasing behavior, a survey questionnaire was designed and distributed to a calculated sample size within the student population at Queen's University located in Kingston, Ontario. Additional data were obtained from Lakehead University to verify the survey results conducted at Queen's University and to provide more credibility to the research study findings. Data were collected and analyzed consequently and the results indicated a strong trend of university students' being concerned about the impacts of the financial crisis, with high possible changing behavior to save money through shifting from purchasing brand products to store products, focusing only on necessary items, and eliminating entertainment costs as much as possible.

Kelisha and Krishna (2013) examined shopping habits, brand loyalty and brand preference during a recession. The study was conducted among a sample of 313 customers at a major mall in Pietermaritzburg, KwaZulu-Natal, South Africa to determine consumers perceptions of private label brands versus manufacturer brands during an economic recession

and, to ascertain whether higher Living Standard Measure (LSM) groups are loyal to established manufacturer brands or if they switch to private label brands during an economic recession.

Relationships were postulated among several variables by developing nine hypotheses and, evaluating these using Chi-square and Spearman's correlation. The study ascertained that a strong negative relationship exists between the respondents change in shopping habits during the recession (to suit their budget) and, their preference for Manufacturer brands compared to Private-label brands.

\section{METHODOLOGY}

The study adopted descriptive survey approach. This work was carried out in South East-Region of Nigeria. The study was carried out in Aba, Enugu and Onitsha. Only users of five selected imported foods in these cities were examined. The imported foods selected for the study include processed food, beverages, baby foods, foreign rice and smoked foods (stockfish). Primary sources of data were employed in this study. The population of the study comprise of all users of five selected imported goods in the selected cities in South=East Region of Nigeria. Cochran formula was employed to determine a sample size of 384.

Prior to data analysis using statistical software package, the SPSS, the questionnaire was be coded, then responses keyed and data cleaning processes were carried out. The data cleaning

ensures that errors during data entry could be detected before final analysis. Person correlation was employed to determine the effect of economic recession on consumer buying behaviour.

\section{DATA PRESENTATION AND ANALYSIS}

Pearson correlation was employed to measure the strength of relationship between variables especially between the dependent and independent variables. And to measures the existence or otherwise of multicolinearity in the research model. The result of the analysis is presented in table below.

Table: Correlation Matrix

\begin{tabular}{|c|c|c|c|c|c|c|}
\hline & & $\begin{array}{l}\text { Economic } \\
\text { Recession }\end{array}$ & $\begin{array}{c}\text { Brand } \\
\text { Switching } \\
\text { Behaviour }\end{array}$ & $\begin{array}{c}\text { Price } \\
\text { Conscious } \\
\text { Behaviour }\end{array}$ & $\begin{array}{c}\text { Impulse } \\
\text { Buying } \\
\text { Behaviour }\end{array}$ & $\begin{array}{c}\text { Consumer } \\
\text { Shopping } \\
\text { Habits }\end{array}$ \\
\hline Economic & $\begin{array}{l}\text { Pearson } \\
\text { Correlation }\end{array}$ & 1 & $.604 "$ & $.544^{*}$ & $.510^{*}$ & $.602^{*}$ \\
\hline Recession & Sig. (2-tailed) & & .009 & .001 & .004 & .020 \\
\hline & $\mathrm{N}$ & 371 & 371 & 371 & 371 & 371 \\
\hline & Pearson & $.604 "$ & 1 & $.112^{*}$ & $-.135^{\star *}$ & .031 \\
\hline Brand Switching & Correlation & مח & & 02 & ( & 510 \\
\hline Detiaviuni & $\mathrm{N}$ & 371 & 371 & 371 & 371 & 371 \\
\hline & Pearson & $.544^{*}$ & $.112^{*}$ & 1 & .072 & -.045 \\
\hline Price Conscious & Correlation & & & & & \\
\hline Behaviour & Sig. (2-tailed) & .001 & .031 & & .168 & .382 \\
\hline & $\mathrm{N}$ & 371 & 371 & 371 & 371 & 371 \\
\hline & Pearson & $.510^{*}$ & $-.135^{\star *}$ & .072 & 1 & .079 \\
\hline Impulse Buying & Correlation & & & & & \\
\hline Behaviour & Sig. (2-tailed) & .004 & .009 & .168 & & .057 \\
\hline & & 371 & 371 & 371 & 371 & 371 \\
\hline & Pearson & $.602^{*}$ & .031 & -.045 & .079 & 1 \\
\hline Consumer & Corl & & & & & \\
\hline Shopping Habit & Sig. (2-tailed) & .020 & .549 & .382 & .057 & \\
\hline & $\mathrm{N}$ & 371 & 371 & 371 & 371 & 371 \\
\hline
\end{tabular}

*. Correlation is significant at the 0.05 level (2-tailed).

**. Correlation is significant at the 0.01 level (2-tailed).

Source: SPSS Version 21.0

This publication is licensed under Creative Commons Attribution CC BY.

http://dx.doi.org/10.29322/IJSRP.11.08.2021.p11638

WWW.ijsrp.org 
The table above shows the extent of association between the dependent and independent variables used in the study. Economic recession recorded a correlation coefficient value of .604 with brand switching behaviour which is statistically significant at $5 \%$ level of significance. This indicates that economic recession has very strong positive effect on brand switching behaviour for fast moving consumer goods in Delta State. Also, economic recession recorded a correlation coefficient of .544 with price conscious behavior with a probability value of .001 which is statistically significant at $5 \%$ level. This implies that economic recession has a strong positive effect on price conscious behavior for imported foods in South-Region of Nigeria.

Furthermore, economic recession recorded a correlation coefficient value of .510 with impulse buying behaviour with a probability value of .004 which is statistically significant at 5\% level. This indicates that economic recession has a strong positive effect on impulse buying behavior for imported foods in South-East Region of Nigeria. Also, economic recession recorded a correlation coefficient value of .602 with consumers' shopping habits with a probability value of .020 which is statistically significant at $5 \%$ level. This implies that economic recession has a very strong positive effect on consumers' shopping habits for imported foods in the Region. Finally, since there is no correlation coefficient in greater than 0.8 which is the rule of thumb, we conclude that explanatory variables are not perfectly linearly correlated. Therefore, there is no problem of multicolinearity in the model used in this study.

\section{DISCUSSION OF FINDINGS}

This work examined the economic recession and its effect on consumer buying behaviour for selected imported foods in the South-East Region of Nigeria. The study found that economic recession has a significant effect on brand switching behavior for imported foods in South-East Region. This agrees with the assertion of Mansoor and Jalal (2011) that during a recession, consumers have been observed to switch from the brand they are used to buying to alternative. This also agrees with the findings of Ang et al (2000) that consumers moved from better known to lesser-known brands during recession. In addition Ang et al (2000) found that brand switching was less common for products with a high-perceived risk and strong brand equity. The study also found that economic recession has a significant effect on price conscious behavior for imported foods in South-East Region of Nigeria. This agrees with the assertion of Mansoor and Jalal (2011) that consumers become sensitive to lower priced brands (Mansoor \& Jalal, 2011). This further agrees with the findings of Obai, 2015 that consumer is extremely sensitiveto to the price of goods and services during recession period. Furthermore, Sharma and Sonwalkar (2013) noted that consumers in a recession appreciate low prices and price was a core attribute when making a purchasing decision.

The study further found that economic recession has a significant effect on impulse buying behavior for imported foods in South-East Region of Nigeria. This agrees with the findings of Eurostat European Commission, (2009),-UK Consumers Survey in 2009 that UK consumer was observed to do more preparation before shopping, such as following a shopping list and not buying other items than were on the list. Shipchandler (1982) reported similar behavior among US consumers. Finally, the study found that economic recession has a significant effect on consumers' shopping habits for in South-East Region of Nigeria. This agrees with the findings of Mansoor and Jalal (2011) consumer shopping behaviour changes during the period of recession. The finding is also similar to that of Masarrat and Jha (2014) that recession has impact on the shopping behaviour of the customers.

\section{FINDINGS}

Data were sourced from consumer of imported foods in Aba, Enugu and Onitsha. The data generated were analyzed, using Pearson correlation analysis..The study found that:

1. Economic recession has a significant effect on brand switching behavior for imported foods in South-East Region of Nigeria.

2. Economic recession was found to have significant effect on price conscious behavior for imported foods in South-East Region of Nigeria, Nigeria.

3. The study found that economic recession has a significant effect on impulse buying behavior and that economic recession has a significant effect on consumers' shopping habits for imported foods in South-East Region of Nigeria,

\section{CONCLUSION}

Based on the foregoing, the study concludes that economic recession has significant effect on consumer buying behaviour for selected imported foods in South-East Region of Nigeria..

\section{RECOMMENDATIONS}

Based on the findings and conclusion, the study recommends that:

1. Companies and/or dealers should monitor the behaviour of their consumers in order to reduce the effect of branding switching behaviour during recession on their products.

2. Companies and/or dealers should also be price sensitive during the period of recession in order not to lose their customer to competing brands.

3. Furthermore, companies should monitor the shopping habits of their consumer during recession in order to mitigate its effect on their sales. 


\section{REFERENCES}

Abishek, E.

http://www.differencebetween.net/business/difference-between-recession-and-depression.

Amadeo, K. (2017). What is a recession? Examples, impact, benefits. Retrieved from https://www.thebalance.com/what-is-arecession-3306019 on 7th April, 2017.

Amalia, P., \& Ionut, P. (2009). Consumers' reaction and organizational response in crisis context, Uni. Of Oradea. The Journal of the Faculty of Economics, 1(5), 779-782.

Ang, S. H., leong, S. M., \& Kotler, P. (2000). The Asian apocalypse: Crisis marketing for consumer and businesses. Long Range Planning, 33(1), 97 - 119.

Ang, S. H.; Leong, S. M., \& Kotler, P. (2000). The Asian apocalypse: Crisis marketing for consumers and businesses. Long Range Planning, 33(1), 97-119.

Arnould, E., Price, L., \& Zinkhan, G. (2002). Consumers, (2nd ed.). McGraw-Hill, New York.

Chaudhuri, A. (2006). Emotion and reason in consumer behaviour. London: Butterworth-Heinemann.

Curtin, R. (2003). What recession? What recovery? The arrival of the $21^{\text {st }}$ century consumer. Business Economics 38 (2): 25-32.

East, R. (1997). Consumer behaviour: Advances and applications in marketing. London: Prentice-Hall.

Eurostat European Commission (2009). Consumers in Europe. Luxembourg: Office for Official Publications of the European Communities.

Flatter, P. \& Willmott, M. (2009). Understanding the post-recession consumers. Harvard Business Review, 87(7/8), 106 - 112.

Foxall, G., \& Goldsmith, R. (1994). Consumer psychology for marketing. London: Routledge.

Ghe. S, (2009). Could be the international financial Crisis: A Sinonim to a profound recession of the Romanian economy? A Theory of weak statistical signs, The Romanian Economic Journal, 31, 99-114.

Hansen, T. (2006). Determinants of consumers' repeat online buying of groceries. International Review of Retail, Distribution and Consumer Research, 16(1), 93 - 114.

Havlena, W., \& Holbrook, M. (1986). The varieties of consumption experience: Comparing two typologies of emotion in consumer behaviour. The Journal of Consumer Research. 13(3), 394-404.

Hrund, E. (2016). The impact of economic crisis on buying behavior and consumer attitude. Masters Thesis Submitted to School of Business, Reykjavik University.

Kar, M. (2010). Consumer behavior over the last 25 years. Retail Digest, 46 - 53.

Kelisha, G., \& Krishna, G. (2013). Shopping habits, brand loyalty and brand preference: Exploring consumers behaviour during a recession. Business Management and Strategy, 4(2), 12 - 28.

Kiran, S. (2011). Impact of recession on buying behavior of Indian consumers. International Review of Business Research Papers, 7(1), 381- 392.

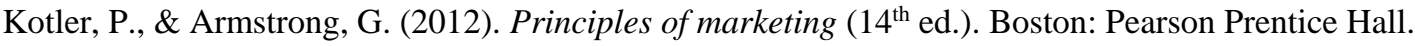

Kumra, R. (2007). Consumer behaviour. Mumbai: Global Media.

Laros, F., \& Steenkamp, J. B. (2005). Emotions in consumer behaviour: hierarchical approach. Journal of

Business Research, 58 (10), 1437 - 1445.

Lim, N. (2003). Consumers' perceived risk: Sources versus consequences. Electronic Commerce Research and Applications, 2(3), 216-228.

Mansoor, D., \& Jalal, A. (2011). The global business crisis and consumer behavior: Kingdom of Bahram as a case study. International Journal of Business and Management, 6(1), 104 - 115.

Masarrat, G., \& Jha, S. (2014). Assessing the impact of recession on consumer's behaviour: An empirical study in Dubai. Academic journal article Researchers World, 23(1), 131 - 142.

Modi, S., \& Jhulka, T. (2012). Consumer buying behavior. Changing shopping patterns. International Journal of Business Management and Economic Research, 3(3), 527 - 530.

Nistorescu, T. \& Puiu, S. (2009). Marketing strategies used in crisis: Case study. MPRA Paper 17743, University Library of Munich, Germany.

Noko, E. J. (2016). Economic recession in Nigeria: Causes and solution. Retrieved from http://educacinfo.com/economic-recessionnigeria/ on 7th April, 2017.

Obai, M. (2015). Effects of Canadian recession on university students' buying behavior. Global Journal of Management and Business Research: E Marketing, 15(8), 18 - 31.

Perner, L. (2008). Consumer behaviour: The psychology of marketing. Uni. of Southern California.

Perriman, H.E., Ramsaran-Fowdar, R.R., \& Baguant, P. (2010). The impact of the global financial crisis on consumer behaviour. Proceedings of the 2010 Annual London Business Research Conference, published by World Business Institute Australia, Melbourne.

Peter, P., \& Olson, J. (2007). Consumer behaviour. London: McGraw-Hill.

Pop, D., \& Rosca, D. (2009). Impact of economic and financial crisis on individual consumer behavior. Annals of Oradea University, Faculty of Engineering and Technology Management, 8.

Posthuma, R., \& Dworkin, J. (2000). A behavioural theory of arbitrator acceptability. International Journal of Conflict Management, 11(3), 249-266.

This publication is licensed under Creative Commons Attribution CC BY.

http://dx.doi.org/10.29322/IJSRP.11.08.2021.p11638

WwW.ijsrp.org 
Reinhart, M. C., \&. Rogoff, K. S. (2009). The aftermath of financial crises. Cambridge: National Bureau of Economic Research. Samuleson, P. A., \& Nordhaus, W. D. (2000). Ekonomia 2. Bratislava: Bradlo.

Saurabh, K., \& Devik, S. (2014). The effect of recession on the buying behavior of consumers in New Delhi during the economic slowdown of 2013. Journal of Business and Management, 16(6), 203 - 209.

Sharma, V., \& Sonwalkar, J. (2013). Does consumer buying behavior change during economic crisis. International Journal of Economics and Business Administration, 1(2), 33 - 48.

Shim, S., Eastlick, M., Lotz, S., \& Warrington, P. (2001). An online prepurchase intentions model: The role of intention to search. Journal of Retailing, 77, 397-416.

Shipchandler, Z. E. (1982). Keeping down with the Joneses: Stagflation and buyer behavior. Business Horizons, $25(6), 32$.

Sinem, E. B. (2014). Effect of economic crisis on food consumption behaviour of British Consumers. International Journal of Education and Research, 2(1), 289 - 316.

Solomon, M. R. (2009), Consumer behaviour: Buying, having and being, 8th edition, New Jersey: Pearson International Edition.

Stijn, C., \& Kose, M. A. (2009). Forthcoming, American recessions: Domestic and global implications. IMF Working Paper, Washington: International Monetary Fund.

Stijn, C., Kose, M. A., \& Terrones, M. (2008). What happens during recessions, crunches, and busts?. IMF Working Paper 08/274, Washington: International Monetary Fund.

Sultan, Z. (2016). What is economic recession? Definition, causes \& effects. Retrieved from https://www.linkedin.com/pulse/whateconomic-recession-definition-causes-effects-sultan-zafar on 7th April, 2017.

Valaskova, K., \& Klieštik, T. (2015). Behavioural reactions of consumers to economic recession. Business: Theory and Practice, 16(3), $290-303$.

Wells, W., \& Prensky, D. (1997). Consumer behaviour. London: John Wiley \& Sons. 